(c) American Dairy Science Association, 2005.

\title{
Use of Chitosan to Prolong Mozzarella Cheese Shelf Life
}

\author{
C. Altieri, C. Scrocco, M. Sinigaglia, and M. A. Del Nobile \\ Department of Food Science, University of Foggia, 25-71100 Foggia, Italy
}

\begin{abstract}
This study was undertaken to evaluate the feasibility of using chitosan, a natural antimicrobial substance, to improve the preservation of a very perishable cheese. The effectiveness of chitosan to inhibit the growth of spoilage microorganisms in Mozzarella cheese was studied during refrigerated storage. A lactic acid/chitosan solution was added directly to the starter used for Mozzarella cheese manufacturing. Mozzarella cheese samples were stored at $4^{\circ} \mathrm{C}$ for about $10 \mathrm{~d}$ and microbial populations as well as the $\mathrm{pH}$ were monitored. Results demonstrated that chitosan inhibited the growth of some spoilage microorganisms such as coliforms, whereas it did not influence the growth of other microorganisms, such as Micrococcaceae, and lightly stimulated lactic acid bacteria.
\end{abstract}

(Key words: Mozzarella cheese, chitosan, shelf life, natural antimicrobial substance)

\section{INTRODUCTION}

Mozzarella cheese is a typical Mediterranean pasta filata product, cut and manufactured in various shapes, and usually brined. It is characterized by a notable economic relevance because of the steady rise in its production and consumption. It is very popular with Italian consumers, both as a fresh cheese and as an ingredient. Numerous studies have characterized this cheese from a microbiological point of view (Ottogalli et al., 1985; Massa et al., 1992; Altieri et al., 1994), recovering several microbial species, such as Lactobacillus lactis subsp. lactis, L. lactis subsp. diacetylactis, L. lactis subsp. cremoris, Streptococcus thermophilus, enterococci such as Enterococcus faecium and E. faecalis, Enterobacteriaceae such as Escherichia coli, some yeasts such as Debaryomyces hansenii and Kluyveromyces marxianus, and various spoilage psychrophilic microflora (Cantoni et al., 2003a,b; Parisi, 2003a,b). Owing to the variety of microorganisms found in this product, Mozzarella has a rather short shelf life.

Received March 7, 2005.

Accepted April 22, 2005.

Corresponding author: M. A. Del Nobile; e-mail: ma.delnobile@ unifg.it
Numerous studies have underlined that fairly often, Mozzarella cheese is spoiled by Pseudomonas spp. growing on the cheese surface, mostly coming from water used during manufacture (Cabrini and Neviani, 1983; Cantoni et al., 2003a,b). Another factor limiting Mozzarella cheese shelf life is the presence of coliforms (Rondinini and Garzaroli, 1990; Parisi, 2003a,b). The same studies demonstrated that proteolytic and lipolytic reactions also are of high importance in Mozzarella cheese preservation. At present, Mozzarella cheese shelf life is approximately 5 to $7 \mathrm{~d}$, and efforts are in progress to prolong this shelf life by means of process innovation (Brody, 2001) and raw materials quality improvement. The use of chitosan as an antimicrobial agent to prolong the shelf life of packed Mozzarella cheese could be viable because it is environmentally friendly and relatively inexpensive. This is because chitosan is a deacetylated form of chitin, the second most abundant biopolymer on earth after cellulose. It has 3 types of reactive functional groups: an amino group and both primary and secondary hydroxyl groups (Furusaki et al., 1996). This substance has been of interest in the past few decades because of its potential range of industrial applications, but few efforts have been performed in food applications, in spite of literature evidence regarding its effectiveness in inhibiting microbial growth. Wang (1992) observed complete inactivation of Staphylococcus aureus after $2 \mathrm{~d}$ of incubation at $\mathrm{pH} 5.5$ in presence of 0.5 to $1.0 \%$ chitosan; furthermore, Darmadji and Izumimoto (1994) registered an interesting effect of chitosan in meat preservation, in particular against $E$. coli. Simpson et al. (1997) studied the antimicrobial effect of chitosan on raw shrimp; using different concentrations of chitosan, they observed variations in the shrimp's microbial susceptibility to chitosan. Shahidi et al. (1999) demonstrated antimicrobial effects of watersoluble chitosan on different bacterial species, such as Bacillus cereus, Proteus vulgaris, and E. coli.

Chitosan is very versatile and it may be used in various applicative areas, as an antimicrobial agent, as an edible film, as an additive, or to improve nutritional quality (Shahidi et al., 1999).

The aim of this work was to test the effectiveness of low-molecular-weight chitosan as a natural antimicrobial additive in Mozzarella cheese. In particular, the experiment aimed to prolong Mozzarella cheese shelf 
Table 1. Effect of chitosan against lactic acid bacteria in different control points during Mozzarella cheese manufacture. ${ }^{1}$

\begin{tabular}{llccc}
\hline Control point & $\begin{array}{l}\text { Time } \\
\text { (days) }\end{array}$ & Mozzarella (cfu/g) & $\begin{array}{l}\text { Mozzarella with } \\
\text { chitosan }(\mathrm{cfu} / \mathrm{g})\end{array}$ & $P$-value \\
\hline Milk & $\mathrm{t}_{0}$ & & $5.60 \times 10^{5} \pm 5.65 \times 10^{4}$ & - \\
Milk + whey & $\mathrm{t}_{1}$ & $4.75 \times 10^{7} \pm 2.47 \times 10^{7}$ & $4.05 \times 10^{7} \pm 6.36 \times 10^{6}$ & 0.76 \\
When pH reached 6.45 & $\mathrm{t}_{2}$ & $4.75 \times 10^{7} \pm 3.54 \times 10^{6}$ & $4.20 \times 10^{7} \pm 8.49 \times 10^{6}$ & 0.52 \\
Curd break & $\mathrm{t}_{3}$ & $2.75 \times 10^{6} \pm 3.54 \times 10^{5}$ & $2.65 \times 10^{6} \pm 4.95 \times 10^{5}$ & 0.84 \\
\hline
\end{tabular}

${ }^{1}$ Numbers reported (cfu/g) represent means of duplicate counts. Data are presented \pm standard deviation.

life, by using chitosan to inhibit the growth of spoilage bacteria.

\section{MATERIALS AND METHODS}

\section{Mozzarella Cheese Manufacture}

The Mozzarella cheese used in this work was made according to the following procedure: $50 \mathrm{~L}$ of milk $(\mathrm{pH}$ 6.7) was put into a boiler and a revitalized Streptococcus salivarius subsp. thermophilus strain was prepared from a freeze-dried culture (Lyoto ST 5.64, ClericiSacco, Como, Italy; optimal temperature $=32$ to $45^{\circ} \mathrm{C}$; no gas) and was used as graft in 1:10 ratio. When milk acidity reached $\mathrm{pH} 5.5$, temperature was raised to $36^{\circ} \mathrm{C}$ and $20 \mathrm{~mL}$ of liquid rennet was added. After $30 \mathrm{~min}$, the curd was cut and a 5-h ripening was carried out. Afterward, the curd was gently stirred to facilitate whey ejection; in this phase, the curd $\mathrm{pH}$ was approximately 4.5. Hot water $\left(82^{\circ} \mathrm{C}\right)$ was used to mill and mold the cheese pieces that were worked by hand until they were adequately smooth and elastic (it took approximately $10 \mathrm{~min}$ ). Then 50-g Mozzarella balls were formed, put into cold water, packaged by hand, and kept in a $12 \%$ $\mathrm{NaCl}$ (wt/wt) brine for the entire storage time. Plastic bags (nylon/polyethylene, $100 \mu \mathrm{m}$; Tecnovac, San Paolo D'Argon, Bergamo, Italy) were used; they were $170 \times$ $250 \mathrm{~mm}$, with properties specified by the manufacturer as follows: test temperature $=23^{\circ} \mathrm{C} ; \Delta \mathrm{RH}(\%)=0.885$; water vapor transmission rate $=1.45 \mathrm{~g} \cdot \mathrm{m}^{-2} \cdot \mathrm{d}^{-1}$; water vapor pressure $=22.4 \mathrm{mmHg}$; permeance $=0.0656 \mathrm{~g}$. $\mathrm{m}^{-2} \cdot \mathrm{g}^{-1} \cdot \mathrm{mmHg}^{-1}$; permeability $=7.31 \cdot 10^{-6} \mathrm{~g} \cdot \mathrm{m} \cdot \mathrm{m}^{-2}$. $\mathrm{day}^{-1} \cdot \mathrm{mmHg}^{-1} ; 6.43 \cdot 10^{-10} \mathrm{~g} \cdot \mathrm{cm} \cdot \mathrm{cm}^{-2} \cdot \mathrm{sec}^{-1} \cdot \mathrm{atm}^{-1}$. The packaged cheese was stored at $4^{\circ} \mathrm{C}$ for the entire observation time (9 d). Simultaneously, a modified Mozzarella cheese was manufactured, adding a low-molecular-weight chitosan (85\% deacetylation) (Aldrich, Milan, Italy). Briefly, a chitosan solution was prepared into the whey and the modified whey was put into the working milk in order to get a final concentration of $0.075 \%$ chitosan. The Mozzarella manufacture was carried out as described above.

Two independent manufacturing processes were performed for normal and modified Mozzarella cheese, and they will be known heretofore as M1 and M2.

\section{Microbiological Analyses}

The number of total coliforms and lactic acid bacteria was monitored in 4 different control points, as follows: 1) into milk; 2) into milk + graft and chitosan solution; 3) when $\mathrm{pH}$ reached 5.5 ( $\mathrm{pH}$ useful to cut the curd); and 4) after the ripening time. Moreover, cell loads were determined on the finished Mozzarella cheese and during storage. The following media and the incubation conditions used were: spread plating onto plate count agar (Biolife, Milan, Italy) plates incubated at $37^{\circ} \mathrm{C}$ for $48 \mathrm{~h}$ for total mesophilic bacteria; spread plating onto plate count agar plus 5\% skim milk (Biolife) plates incubated at $30^{\circ} \mathrm{C}$ for $5 \mathrm{~d}$ for proteolytic bacteria; spread plating onto trybutyrin agar (Oxoid, Milan, Italy) plates incubated at $30^{\circ} \mathrm{C}$ for $72 \mathrm{~h}$ for lipolytic bacteria; pour plating in violet red bile agar (Oxoid), with a covering layer of the same medium, incubated at $37^{\circ} \mathrm{C}$ for $24 \mathrm{~h}$ for total coliforms; spread plating onto Pseudomonas agar base with selective supplement (Oxoid) plates in-

Table 2. Effect of chitosan against coliforms in different control points during Mozzarella cheese manufacture. $^{1}$

\begin{tabular}{llccc}
\hline Control point & $\begin{array}{l}\text { Time } \\
\text { (days) }\end{array}$ & Mozzarella $(\mathrm{cfu} / \mathrm{g})$ & $\begin{array}{l}\text { Mozzarella with } \\
\text { chitosan }(\mathrm{cfu} / \mathrm{g})\end{array}$ & $P$-value \\
\hline Milk & $\mathrm{t}_{0}$ & & $6.30 \times 10^{3} \pm 9.89 \times 10^{2}$ & - \\
Milk + whey & $\mathrm{t}_{1}$ & $4.35 \times 10^{4} \pm 9.19 \times 10^{3}$ & $3.75 \times 10^{4} \pm 3.54 \times 10^{3}$ & 0.52 \\
When pH reached 6.45 & $\mathrm{t}_{2}$ & $2.60 \times 10^{4} \pm 5.66 \times 10^{3}$ & $4.75 \times 10^{3} \pm 3.53 \times 10^{2}$ & 0.12 \\
Curd break & $\mathrm{t}_{3}$ & $2.85 \times 10^{3} \pm 1.20 \times 10^{3}$ & $4.05 \times 10^{2} \pm 7.7 \times 10$ & 0.21 \\
\hline
\end{tabular}

\footnotetext{
${ }^{1}$ Numbers reported (cfu/g) represent means of duplicate counts. Data are presented \pm standard deviation.
} 
cubated at $25^{\circ} \mathrm{C}$ for $48 \mathrm{~h}$ for Pseudomonas spp.; pour plating in Slanetz-Bartley agar (Oxoid) incubated at $37^{\circ} \mathrm{C}$ for $48 \mathrm{~h}$ for enterococci; spread plating onto mannitol salt agar (Oxoid) plates incubated at $32^{\circ} \mathrm{C}$ for $72 \mathrm{~h}$ for Micrococcaceae; pour plating in DeMan, Rogosa, and Sharpe agar (Oxoid) incubated in anaerobic conditions for $48 \mathrm{~h}$ at 35 or $42^{\circ} \mathrm{C}$ for mesophilic and thermophilic lactic acid bacilli, respectively; pour plating in M17 agar (Oxoid) incubated at $35^{\circ} \mathrm{C}$ for $48 \mathrm{~h}$ for lactic acid streptococci; spread plating onto Sabouraud dextrose agar (Oxoid) plates incubated at $25^{\circ} \mathrm{C}$ for $48 \mathrm{~h}$ or $5 \mathrm{~d}$ for yeasts and molds, respectively.

Microbiological data are the average of 2 replicates.

\section{Chemical Analyses: pH Evaluation}

The $\mathrm{pH}$ was evaluated for the milk, the Mozzarella cheese pieces, and the brine water mix. A pH meter (Crison, Micro-pH2001, PBI, Milan, Italy) was used. Data are the average of 2 replicates.

\section{Sensory Evaluation}

A simple, unstructured sensory evaluation was performed by 5 trained people every time the samples were opened for laboratory analyses, and the following parameters were considered: color, flavor, texture, and odor. The tasters evaluated the 4 parameters on a hedonistic scale of 0 to 4 ( $0=$ unacceptable; $1=$ poor; $2=$ fair; $3=$ good; 4 = very good).

\section{Shelf Life Calculation}

As reported in the literature, the Gompertz equation as modified by Zwietering has often been used to determine the shelf life of packed foods (Lanciotti et al., 1999; Riva et al., 2000; Corbo et al., 2003; Sinigaglia et al., 2003). The method generally adopted (Zwietering et al., 1990) consists of estimating the Gompertz parameters by fitting the following equation to the experimental data:

$$
\begin{gathered}
\log \left(\frac{\mathrm{cfu}}{\mathrm{g}}\right)=\mathrm{K}+\mathrm{A} \cdot \\
\exp \left\{-\exp \left\{\left[\left(\mu_{\max } \cdot 2.7182\right) \cdot \frac{\lambda-\mathrm{t}}{\mathrm{A}}\right]+1\right\}\right\}
\end{gathered}
$$

where $\mathrm{K}$ is the initial level of microbial count, $\mathrm{A}$ is the maximum bacteria growth attained at the stationary phase, $\mu_{\max }$ is the maximal specific growth rate, $\lambda$ is the lag time (days), and $t$ is the time. Once the Gompertz's parameters are estimated the shelf life (S.L.) of the produce is calculated through the following expression:

$$
\text { S.L. }=\lambda-\frac{\mathrm{A} \cdot\left\{\ln \left[-\ln \left(\frac{\left[\log \left(\frac{\mathrm{cfu}}{\mathrm{g}}\right)\right]_{\max }-\mathrm{K}}{\mathrm{A}}\right)\right]-1\right\}}{\mu_{\max } \cdot 2.7182}
$$

where $\left[\log \left(\frac{\mathrm{cfu}}{\mathrm{g}}\right)\right] \max _{\text {mas }}$ is the decimal logarithm of the microbial acceptability limit. It is worth noting that even when it is possible to use Equation [1] to estimate the confidence interval of each of the Gompertz parameters, it is not possible to estimate the confidence interval of the shelf life as it does not compare implicitly in Equation [1]. The impossibility of estimating the shelf life confidence interval is the main drawback of using the above approach to estimate the shelf life of fresh products.

To calculate the shelf life of the packed Mozzarella cheese, the approach proposed by Corbo et al. (2004) was adopted. It consists in rearranging Equation [1] in such a way that the shelf life appears directly as a parameter of the equation relating $\log (\mathrm{cfu} / \mathrm{g})$ to storage time:

$$
\begin{gathered}
\log \left(\frac{\mathrm{cfu}}{\mathrm{g}}\right)=\left[\log \left(\frac{\mathrm{cfu}}{\mathrm{g}}\right)\right] \max _{\text {max }}- \\
\mathrm{A} \cdot \exp \left\{-\exp \left\{\left[\left(\mu_{\max } \cdot 2.71\right) \cdot \frac{\lambda-\mathrm{S} . \mathrm{L} .}{\mathrm{A}}\right]+1\right\}\right\}+ \\
+\mathrm{A} \cdot \exp \left\{-\exp \left\{\left[\left(\mu_{\max } \cdot 2.71\right) \cdot \frac{\lambda-\mathrm{t}}{\mathrm{A}}\right]+1\right\}\right\}
\end{gathered}
$$

By fitting Equation [3] to the experimental data it is possible to estimate the equation's parameters and their confidence interval. Therefore, Equation [3] can be used in place of Equations [1] and [2] to determine both the shelf life of the packed product and its confidence interval.

\section{Statistical Analyses}

All analyses were carried out in duplicate. The media and standard deviations were calculated. The data shown in the figures and tables are the average of all repetitions, whereas the error bars are the standard deviation.

The confidence intervals of model's parameters were evaluated as follows: first, a fit was run with the original data; then, using the data points standard deviation, 100 additional fits were run on artificial data sets, which were generated by randomly varying the data around the fitted function. From these additional fits, a distribution of values for each parameter was obtained. The sets of data obtained for each parameter were statistically treated to obtain the $95 \%$ confidence interval. 


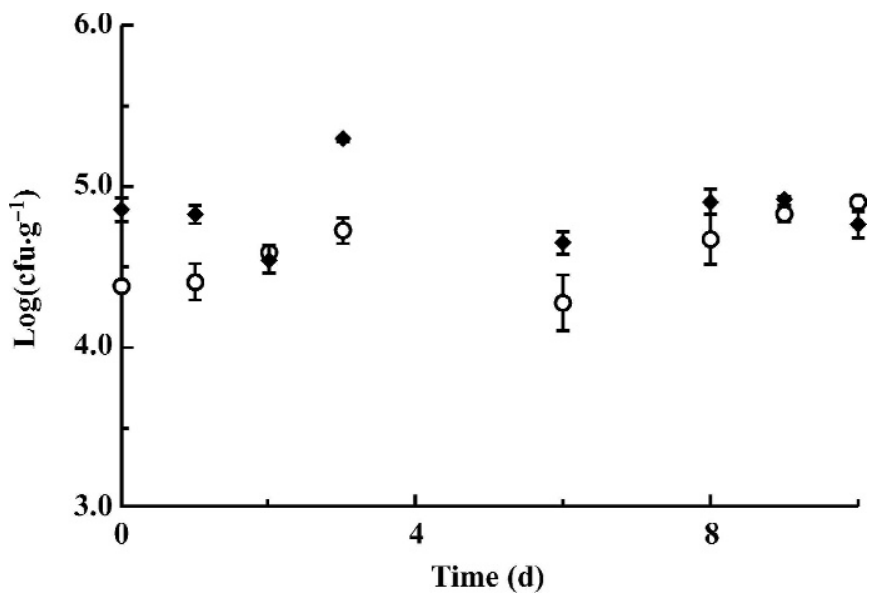

Figure 1. Time course during storage of lactic bacilli concentration in Mozzarella stored at $4^{\circ} \mathrm{C}$, test M1. without chitosan; $\bigcirc$ with chitosan.

The unpaired Student $t$-tests with unequal variance were run using Kaleidagraph software (Synergy Software, Reading, PA).

\section{RESULTS AND DISCUSSION}

The cell number of lactic acid bacteria and coliforms during the $\mathrm{M} 1$ cheese manufacture are reported in tables 1 and 2, respectively. As can be inferred, there was no significant difference $(P>0.05)$ between samples with chitosan and those that were chitosan-free for both microbial groups. With regard to lactic acid bacteria, this result could indicate that chitosan influenced neither cell viability and growth nor functional and technological

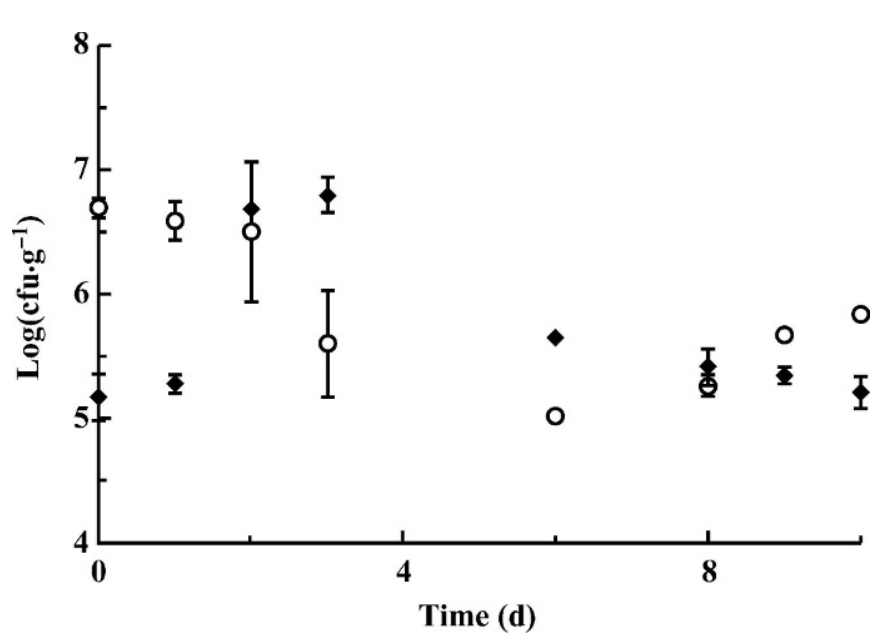

Figure 2. Time course during storage of streptococci concentration in Mozzarella stored at $4^{\circ} \mathrm{C}$, test M1. without chitosan; $\bigcirc$ with chitosan.

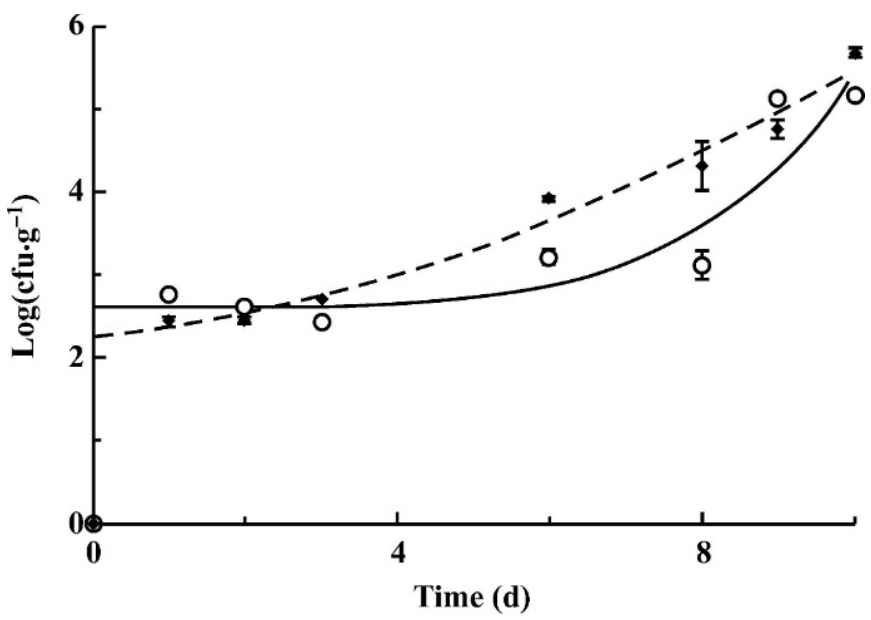

Figure 3. Time course during storage of coliform concentration in Mozzarella cheese stored at $4^{\circ} \mathrm{C}$, test M1. without chitosan; $\bigcirc$ with chitosan. The curves shown in the figure are the best fit of reparameterized Gompertz equation to experimental data. (-- ) without chitosan; (-) with chitosan.

properties. Also, Ouattara et al. (2000) have verified that chitosan had no or little effect on the numbers of lactic acid bacteria on the surface of bologna or pastrami after $21 \mathrm{~d}$ of storage at 4 or $10^{\circ} \mathrm{C}$.

With regard to coliforms, even if the differences recorded were not statistically significant, cell load means were always lower in the samples with chitosan than in those without, suggesting that coliforms seemed to be slightly inhibited by chitosan.

Numerous studies have shown the effect of chitosan on Escherichia coli and other Enterobacteriaceae at dif-

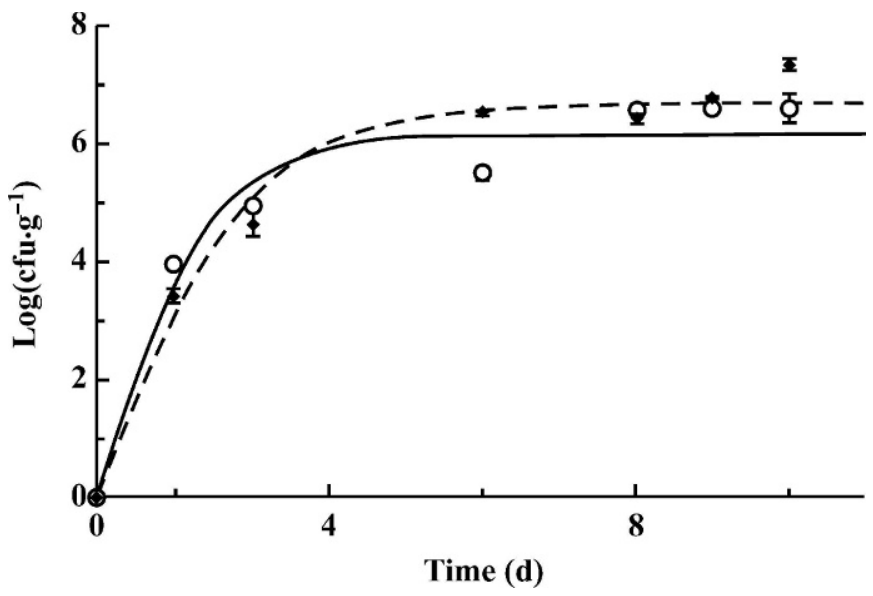

Figure 4. Time course during storage of Pseudomonas spp. concentration in Mozzarella cheese stored at $4^{\circ} \mathrm{C}$, test M1. without chitosan; $\bigcirc$ with chitosan. The curves shown in the figure are the best fit of reparameterized Gompertz equation to experimental data. $(---)$ without chitosan; (-) with chitosan. 
Table 3. Calculated shelf life referred to total coliforms in Mozzarella cheese, as affected by chitosan.

\begin{tabular}{|c|c|c|c|}
\hline \multirow[b]{2}{*}{ Sampling } & \multicolumn{2}{|c|}{$\mathrm{SL}(\mathrm{d})^{1}$} & \multirow[b]{2}{*}{$P$-value ${ }^{2}$} \\
\hline & $\begin{array}{l}\text { Mozzarella } \\
\text { with chitosan }\end{array}$ & Control & \\
\hline $\mathrm{M}^{3}$ & $\begin{array}{c}4.6696 \\
{[3.9187,5.3709]}\end{array}$ & $\begin{array}{c}3,9135 \\
{[3.2007,4.5440]}\end{array}$ & $<0.0001$ \\
\hline M2 & $\begin{array}{c}9.2491 \\
{[8.9437,9.5031]}\end{array}$ & $\begin{array}{c}8.0099 \\
{[7.4066,8.4842]}\end{array}$ & $<0.0001$ \\
\hline
\end{tabular}

\footnotetext{
${ }^{1} \mathrm{SL}=$ Predicted shelf life. Data within square brackets represent 95\% confidence intervals.

${ }^{2}$ Significance level of the differences among means, referred to an unpaired Student $t$-tests with unequal variance.

${ }^{3} \mathrm{M} 1$ and M2 represent 2 independent Mozzarella manufacturing processes.
}

ferent concentrations and under different conditions: Ouattara et al. (2000) have demonstrated that the growth of Enterobacteriaceae was delayed or completely inhibited by chitosan application. Moreover, Tsai et al. $(1999,2000)$ have reported that the minimal lethal concentration of a chitooligosaccharide for Salmonella Thyphimurium ranged from 5 and $29 \mathrm{ppm}$, and the same was registered against Escherichia coli O157. Agreeing data were published by other authors, such as Simpson et al. (1997), Wang (1992), and Darmadji and Izumimoto (1994), who tested a range of low doses of chitosan (i.e., from 0.0075 to $1 \%$ ), obtaining a noticeable effect against Enterobacteriaceae.

Figures 1 and 2 show the evolution during storage of lactic acid bacilli and streptococci viable counts. As expected, these microorganisms grew during storage but there were no marked differences between the 2 investigated kinds of Mozzarella samples. Nevertheless, significant differences among mean values $(P<0.05)$ were recorded at the first and third days of storage and on the sixth and ninth days of storage, for bacilli and cocci, respectively. These results could suggest that lactic acid bacilli were affected by the action of chitosan during the first days of storage, whereas streptococci were slightly stimulated only during the last days of storage. Further studies are necessary to set out the mechanisms playing a role in the different bacilli and cocci responses.
Data regarding Micrococcaceae are not reported because they were not affected by chitosan addition, whereas lipolytic bacteria, yeasts, and molds were not recovered from the milk or the Mozzarella cheese.

The dynamics over time of coliforms and Pseudomonas spp. growth are reported in Figures 3 and 4. These spoilage microbial groups demonstrated small differences between samples with and without chitosan; however, the recorded statistical significance $(P<0.05)$ suggested that a certain influence of the studied additive has been expressed. In particular, whereas coliforms were shown to be negatively affected by the chitosan action more in the last storage time (significant differences after 5 days storage), Pseudomonas spp. was showed to be affected already after $3 \mathrm{~d}$ storage. These results may be significant in the evaluation of the shelf life of the tested Mozzarella cheese as the 2 are considered to be the bacterial groups responsible of the most important spoilage phenomena (i.e., surface spoilage, proteolysis) on Mozzarella balls. Consequently, coliforms and Pseudomonas spp. cell load data were used to estimate the shelf life of the investigated samples. The study was conducted according to the procedure reported in the Materials and Methods section; Equation [1] was fitted to the data relative to the above 2 bacterial groups and Figures 1 and 2 show the best fit. According to DPR 54/97 and to

Table 4. Calculated shelf life referred to Pseudomonas spp. in Mozzarella cheese, as affected by chitosan.

\begin{tabular}{|c|c|c|c|}
\hline \multirow[b]{2}{*}{ Sampling } & \multicolumn{2}{|c|}{$\mathrm{SL}(\mathrm{d})^{1}$} & \multirow[b]{2}{*}{$P$-value ${ }^{2}$} \\
\hline & $\begin{array}{l}\text { Mozzarella } \\
\text { with chitosan }\end{array}$ & Control & \\
\hline $\mathrm{M} 1^{3}$ & $\begin{array}{c}6.7292 \\
{[6.1663,7.4952]}\end{array}$ & $\begin{array}{c}4.8498 \\
{[3.6372,5.8578]}\end{array}$ & $<0.0001$ \\
\hline M2 & $\begin{array}{c}4.3275 \\
{[3.5611,12.9261]}\end{array}$ & $\begin{array}{c}3.9639 \\
{[3.7657,4.4023]}\end{array}$ & 0.1264 \\
\hline
\end{tabular}

\footnotetext{
${ }^{1} \mathrm{SL}=$ Predicted shelf life; data within square brackets represent $95 \%$ confidence intervals.

${ }^{2}$ Significance level of the differences among means, referred to an unpaired Student $t$-tests with unequal variance.

${ }^{3} \mathrm{M} 1$ and M2 representing 2 independent Mozzarella manufacturing processes.
} 
Bishop and White (1986), the values of $\left[\log \left(\frac{\mathrm{cfu}}{\mathrm{g}}\right)\right] \max$ were set to 4.5 and 6.0 for coliforms and Pseudomonas spp., respectively. The values in Tables 3 and 4 represent the calculated shelf life with their confidence interval (95\%). As can be inferred from these data, chitosan slowed down the growth of coliforms during Mozzarella storage, leading to a slight increase in the shelf life of the cheese (approximately $1 \mathrm{~d}$ ). This result is related for coliforms to the evident extension of lag phase (Figure 3 ).

It is worth pointing out that this result, even if not relevant, was recorded on different (10 independent batches) production batches (data not shown). The repeatability of the result was verified, even when working with different initial cell loads in the samples. In the case of pseudomonads, samples with chitosan showed a significant shelf life increase, respect to the chitosanfree Mozzarella cheese. This result is related to the reduction of the maximum cell load reached in stationary phase (Figure 4).

The above difference in the microbial growth between chitosan-bearing and chitosan-free samples cannot be ascribed to differences in the $\mathrm{pH}$. For all samples, no differences were detected in the evolution of $\mathrm{pH}$, which never became a limiting factor for the studied bacterial populations.

According to an unstructured sensory analysis, no differences between chitosan and chitosan-free samples were recognized, corroborating the hypothesis that chitosan (at the tested concentrations) does not worsen the sensorial characteristics of the cheese. Moreover, in the Mozzarella with chitosan, the texture was better maintained, contributing to its acceptability. Because no significant differences were recorded between chitosanbearing and chitosan-free samples regarding $\mathrm{pH}$ and sensory characteristics evolution, no data are presented about these evaluations.

\section{CONCLUSIONS}

In conclusion, under the tested conditions, chitosan was effective in inhibiting the growth of spoilage microorganisms such as coliforms and Pseudomonas spp. Moreover, it seems that the presence of chitosan does not affect the growth of lactic acid bacteria, saving the functional dairy microbiota.

It can be concluded that the method studied and proposed in this work could be advantageously used to prolong the shelf life of Mozzarella, allowing for the distribu- tion of this product beyond market borders without added costs.

\section{REFERENCES}

Altieri, C., M. A. Manginelli, and P. Giudici. 1994. Evoluzione della carica microbica della Mozzarella di latte vaccino in rapporto alla tecnologia di produzione. Il Latte 12:1252-1256.

Bishop, J. R., and C. H. White. 1986. Assessment of dairy product quality and potential shelf life-A review. J. Food Protect. 49:739-753.

Brody, A. L. 2001. Say Cheese and package it, please! Food Technol. $55: 76-77$.

Cabrini, A. and E. Neviani. 1983. Il genere Pseudomonas causa di sapore amaro e di odore putrido sulla superficie di formaggio Mozzarella. Il Latte 8:90.

Cantoni, C., L. Iacumin, and G. Comi. 2003a. Alterazione giallo-arancio di Mozzarella. Ind. Alimentari 42:134-136.

Cantoni, C., S. Stella, M. Cozzi, L. Iacumin, and G. Comi. 2003b. Colorazione blu di mozzarelle. Ind. Alimentari 42:840-843.

Corbo, M. R., M. A. Del Nobile, and M. Sinigaglia 2004. Use of reparameterized Gompertz equation for calculating of shelf life of minimally processed vegetables. Proc. Int. Conf. Food Safety, Bologna, Italy.

Darmadji, P., and M. Izumimoto. 1994. Effect of chitosan in meat preservation. Meat Sci. 38:243-254.

DPR 14/1/1997 n. 54. Regolamento recante attuazione delle Dir. 92/ 46 e 92/47/CEE in materia di produzione e immissione sul mercato di latte e di prodotti a base di latte. European Union, Brussels, Belgium.

Furusaki, E., I. Ueno, N. Sakairi, N. Nishi, and S. Tokura. 1996. Facile preparation and inclusion ability of chitosan derivative bearing carboxymethyl- $\beta$-cyclodextrin. Carb. Polym. 9:29-34.

Massa, S., F. Gardini, M. Sinigaglia, and M. E. Guerzoni. 1992. Klebsiella pneumoniae as a spoilage organism in Mozzarella-cheese. J. Dairy Sci. 75:1411-1414.

Ottogalli, G., G. Rondinini, and D. Conti. 1979. Coliformi, Streptococchi fecali e test di sedimentazione su alcuni formaggi freschi. Annali Microbiol. 29:41-47.

Ouattara, B., R. E. Simard, G. Piette, A. Bégin, and R. A. Holley. 2000. Inhibition of surface spoilage bacteria in processed meats by application of antimicrobial films prepared with chitosan. Int. J. Food Microbiol. 62:139-148.

Parisi, S. 2003a. Curve predittive per la crescita dei batteri coliformi in prodotti lattiero-caseari. Ind. Alimentari 42:29-37.

Parisi, S. 2003b. Evoluzione chimico-fisica e microbiologica nella conservazione di prodotti lattiero-caseari. Ind. Alimentari 42:249-259.

Rondinini, G., and C. Garzaroli. 1990. Mozzarelle prodotte per acidificazione chimica: Aspetti microbiologici e alterativi. Ind. Alimentari 29:329-334.

Shahidi, F., J. K. V. Arachchi, and Y. J. Jeon. 1999. Food applications of chitin and chitosan. Trends Food Sci. Technol. 10:37-51.

Simpson, B. K., N. Gagne, I. N. A. Ashie, and E. Noroozi. 1997. Utilization of chitosan for preservation of raw shrimp (Pandalus borealis). Food Biotechnol. 11:25-44.

Tsai, G. J., and W. H. Su. 1999. Antibacterial activity of shrimp chitosan against Escherichia coli. J. Food Prot. 62:239-243.

Tsai, G. J., Z. Y. Wu, and W. H. Su. 2000. Antibacterial activity of a chitooligosaccharide mixture prepared by cellulase digestion of shrimp chitosan and its application to milk preservation. J. Food Prot. 63:747-752.

Wang, G. 1992. Inhibition and inactivation of five species of foodborne pathogens by chitosan. J. Food Prot. 55:916-919.

Zwietering, M. H., I. Jogenburger, F. M. Rombouts, and K. van't Riet. 1990. Modeling of the bacterial growth curve. Appl. Environ. Microbiol. $56: 1875-1881$. 